\title{
Differentiation of the Subspecies of Campylobacter fetus by Genomic Sizing
}

\author{
SAMEEH M. SALAMA, ${ }^{1,2}$ MANUEL M. GARCIA,${ }^{3}$ AND DIANE E. TAYLOR ${ }^{1,2 *}$ \\ Department of Medical Microbiology and Infectious Diseases ${ }^{1}$ and Canadian Bacterial Disease Network, ${ }^{2}$ \\ University of Alberta, Edmonton, Alberta, Canada T6G 2H7, and Animal Diseases Research Institute, \\ Agriculture Canada, Nepean, Ontario, Canada $\mathrm{K} 2 \mathrm{H} 8 \mathrm{P} 9^{3}$
}

\begin{abstract}
Campylobacter fetus subsp. fetus and $C$. fetus subsp. venerealis are currently differentiated by tolerance to glycine and by their epidemiology. Analysis of $C$. fetus DNA by pulsed-field gel electrophoresis, after digestion with the restriction endonucleases $S m a I$ and Sall, was used to differentiate between the subspecies. All strains presently identified as $C$. fetus subsp. fetus had a genomic size of $1.1 \mathrm{Mb}$, whereas the majority of the $C$. fetus subsp. venerealis strains had a genomic size of $1.3 \mathrm{Mb}$. An additional group of strains, which were previously described as $C$. fetus subsp. venerealis biovar "intermedius" and were able to tolerate higher concentrations of glycine than the rest of the $C$. fetus subsp. venerealis strains, had an average genome size of $1.5 \mathrm{Mb}$. We suggest that pulsed-field gel electrophoresis may be useful as an additional aid in the differentiation of $C$. fetus strains at the subspecies level.
\end{abstract}

Strains of Campylobacter fetus subsp. fetus are associated with abortion in sheep and cattle (23-26). Human infections, which include bacteremia and other systemic infections, especially in immunocompromised patients, have been reported previously (4). The virulence of $C$. fetus subsp. fetus has been attributed to the presence of an $S$ layer, composed of a protein with a subunit molecular mass of 97 to $149 \mathrm{kDa}$ $(5,18,30)$. In contrast, strains of $C$. fetus subsp. venerealis have adapted to the bovine genital tract (bovine vibriosis) (23) and are of major concern to the cattle industry due to their ability to cause infertility of cows inseminated with contaminated bull semen (21). Human infections due to $C$. fetus subsp. venerealis have not been reported (14). Attempts to differentiate between the two subspecies on the basis of fluorescent-antibody assay (17), fatty acid contents (6), and DNA-DNA homology studies (3) have not been successful. Moreover, the ability of the strains to produce $\mathrm{H}_{2} \mathrm{~S}$ or to grow on media containing sodium selenite has also been examined, but the results were difficult to interpret (29). The degree of tolerance to glycine and the epidemiology of the organisms are the two main methods currently available for differentiation.

The aim of this study was to assess the use of genomic sizing with the aid of pulsed-field gel electrophoresis (PFGE) to differentiate strains of $C$. fetus at the subspecies level.

\section{MATERIALS AND METHODS}

Culture method for $C$. fetus. The sources and characteristics of the $C$. fetus strains are shown in Table 1. Cultures were stored in $20 \%$ glycerol (BDH, Toronto, Canada) in peptone broth (Oxoid Ltd., Basingstoke, United Kingdom) at $-70^{\circ} \mathrm{C}$. When required, the culture broths were thawed and streaked on plates of brain heart infusion agar (Oxoid Ltd.) containing 5\% whole defibrinated horse blood (Gibmar Laboratories, Edmonton, Canada). The plates were incubated under microaerobic conditions $\left(10 \% \mathrm{CO}_{2}, 10 \% \mathrm{H}_{2}\right.$, $80 \% \mathrm{~N}_{2}$ ) at $37^{\circ} \mathrm{C}$ for up to $72 \mathrm{~h}$. Although all strains have been identified by their original suppliers, their ability to grow at $25^{\circ} \mathrm{C}$, microscopic morphology, and oxidase, cata-

\footnotetext{
* Corresponding author.
}

lase, and nitrate activities were retested immediately prior to this study. The ability of the organisms to tolerate glycine was tested according to Florent's method (11). Briefly, 0.1 $\mathrm{ml}$ of the bacterial cultures, adjusted to a McFarland no. 1 turbidity, were inoculated into fluid Albimi broth containing $0.6,1,1.3$, and $1.9 \%$ glycine, and readings were made after 2 to 3 days of incubation. The final identifications of $C$. fetus subsp. fetus and $C$. fetus subsp. venerealis strains were confirmed by investigation of the type strains ATCC 27374 (UA60) and ATCC 19438 (UA811), respectively.

Preparation of DNA inserts. DNA inserts were prepared as described by Chang and Taylor (7).

Restriction endonuclease digestion. Each DNA insert was washed for $20 \mathrm{~min}$ in $10 \mathrm{mM}$ Tris-EDTA (BDH) containing 1 $\mathrm{mM}$ phenylmethylsulfonyl fluoride (Sigma, St. Louis, Mo.). This step was carried out at least three times and was followed by washing three times in $10 \mathrm{mM}$ Tris-EDTA only. Before enzyme digestion, the Tris-EDTA was removed and replaced by $100 \mu$ l of the appropriate digestion buffer and the insert was incubated at room temperature for $30 \mathrm{~min}$, after which the buffer was replaced with $100 \mu \mathrm{l}$ of fresh enzyme buffer and 50 to $70 \mathrm{U}$ of the appropriate enzyme (SmaI or SalI [Boehringer GmbH, Mannheim, Germany]) (7) was added. The reaction mixture was incubated at $37^{\circ} \mathrm{C}$ for 18 to $24 \mathrm{~h}$. After incubation, the DNA inserts were washed in Tris-EDTA buffer and loaded into 1\% agarose (Bethesda Research Laboratories, Inc., Gaithersburg, Md.) gel wells, which were then sealed with $1 \%$ agarose in gel buffer.

PFGE. The contour-clamped homogeneous electric field (CHEF) system (LKB Instruments Inc., Bromma, Sweden) of PFGE was used to separate the DNA fragments. Gels were subjected to electrophoresis for $24 \mathrm{~h}$ at $8^{\circ} \mathrm{C}$ with a voltage of $175 \mathrm{~V}$ and pulse times of 15 to $25 \mathrm{~s}$ in $0.05 \mathrm{M}$ Tris-borate-EDTA buffer. Following electrophoresis, the gels were stained with ethidium bromide and the DNA fragments were visualized with a UV transilluminator. The sizes of the DNA fragments were determined by measuring distances of band migration compared with the DNA standards of a $\lambda \Delta 39$ DNA ladder (Promega, Madison, Wis.) as well as DNA fragments of Campylobacter jejuni (UA580) and Campylobacter coli (UA417) of known size (7).

DNA-DNA hybridization. DNA fragments of the $C$. fetus strains were separated by CHEF agarose gel electrophoresis 
TABLE 1. Characteristics of $C$. fetus strains

\begin{tabular}{|c|c|c|c|c|c|}
\hline Strain type ${ }^{a}$ & $\begin{array}{l}\mathrm{ADRI}^{b} \\
\text { no. }\end{array}$ & $\mathrm{UA}^{c}$ no. & $\begin{array}{l}\text { Isolation } \\
\text { source }\end{array}$ & $\begin{array}{c}\text { Glycine } \\
\text { tolerance }(\%)\end{array}$ & Source $^{d}$ \\
\hline C. fetus subsp. fetus & $\begin{array}{l}1025 \\
802 \\
1028 \\
1029 \\
1030 \\
1341 \\
553^{\mathrm{T}}\end{array}$ & $\begin{array}{l}\text { UA777 } \\
\text { UA778 } \\
\text { UA779 } \\
\text { UA780 } \\
\text { UA781 } \\
\text { UA782 } \\
\text { UA60 }\end{array}$ & $\begin{array}{l}\text { Human } \\
\text { Ovine } \\
\text { Ovine } \\
\text { Bovine } \\
\text { Bovine } \\
\text { Bovine } \\
\text { Ovine }\end{array}$ & $\begin{array}{l}1.3 \\
1.3 \\
1.5 \\
1.3 \\
1.9 \\
1.9 \\
1.9\end{array}$ & $\begin{array}{l}\text { E. Holst } \\
\text { M. Corbel } \\
\text { CCUG } 10371 \\
\text { CCUG } 10770 \\
\text { CCUG } 17693 \\
\text { A. Cipolla } \\
\text { ATCC } 27374^{T}\end{array}$ \\
\hline C. fetus subsp. venerealis ${ }^{e}$ & $\begin{array}{l}817 \\
544 \\
545 \\
546 \\
812\end{array}$ & $\begin{array}{l}\text { UA790 } \\
\text { UA791 } \\
\text { UA813 } \\
\text { UA814 } \\
\text { UA815 }\end{array}$ & $\begin{array}{l}\text { Bovine } \\
\text { Bovine } \\
\text { Bovine } \\
\text { Bovine } \\
\text { Bovine }\end{array}$ & $\begin{array}{l}1.0 \\
1.0 \\
1.0 \\
1.0 \\
1.0\end{array}$ & $\begin{array}{l}\text { M. Corbel } \\
\text { B. Clark } \\
\text { B. Clark } \\
\text { B. Clark } \\
\text { M. Corbel }\end{array}$ \\
\hline C. fetus subsp. venerealis & $\begin{array}{l}1023 \\
1345 \\
1267^{\mathrm{T}} \\
543 \\
554 \\
555 \\
838\end{array}$ & $\begin{array}{l}\text { UA809 } \\
\text { UA810 } \\
\text { UA811 }^{\mathrm{T}} \\
\text { UA816 } \\
\text { UA817 } \\
\text { UA818 } \\
\text { UA820 }\end{array}$ & $\begin{array}{l}\text { Human } \\
\text { Bovine } \\
\text { Bovine } \\
\text { Bovine } \\
\text { Bovine } \\
\text { Bovine } \\
\text { Bovine }\end{array}$ & $\begin{array}{l}<1 \\
<1 \\
<1 \\
<1 \\
<1 \\
<1 \\
<1\end{array}$ & $\begin{array}{l}\text { E. Holst } \\
\text { A. Cipolla } \\
\text { ATCC } 19438^{\mathrm{T}} \\
\text { B. Clark } \\
\text { H. Lior } \\
\text { B. Firehammer } \\
\text { B. Firehammer }\end{array}$ \\
\hline
\end{tabular}

${ }^{a}$ Strain identified on the basis of tolerance to $>1 \%$ glycine.

$b$ ADRI, Animal Disease Research Institute, Nepean, Ontario, Canada.

$c$ UA, University of Alberta.

${ }^{d}$ Sources of strains are as follows: E. Holst, Department of Medical Microbiology, University of Lund, Lund, Sweden; M. Corbel, Central University Laboratory, Ministry of Agriculture, Fisheries and Food, New Haw Weybridge, Surrey, United Kingdom; A. Cipolla, Instituto Nacional de Technologia Agropewaria-EEA, Balcarce, Argentina; CCUG, Culture Collection, Department of Clinical Bacteriology, University of Göteborg, Göteborg, Sweden; ATCC, American Type Culture Collection, Rockville, Md.; B. Clark, Animal Health Laboratory, Commonwealth Scientific and Industrial Research Organization, Parkville, Victoria, Australia; H. Lior, Laboratory Centre for Disease Control, Ottawa, Ontario, Canada; and B. Firehammer, Veterans Research Laboratory, Montana State University, Bozeman.

e Biovar "intermedius."

after digestion with the restriction endonucleases SmaI and SalI and were transferred to nitrocellulose filters (Bio-Rad, Richmond, Calif.) by the Southern transfer technique described previously (27). Purified chromosomal DNA of $C$. fetus subsp. fetus UA60 ${ }^{\mathrm{T}}$ (ATCC $27374^{\mathrm{T}}$ ) was nick translated and hybridized to the DNA in the nitrocellulose filters, prepared above, by the method described by Maniatis et al. (16). After hybridization, the nitrocellulose filters were exposed to X-ray film (XAR-5; Kodak, Rochester, N.Y.) for up to 1 week at $-80^{\circ} \mathrm{C}$, and the hybridization patterns were analyzed.

\section{RESULTS}

Phenotypic characterization. All $C$. fetus strains tested grew at 25 and $37^{\circ} \mathrm{C}$ but not at $42^{\circ} \mathrm{C}$ and were able to produce oxidase, catalase, and nitrate but failed to generate $\mathrm{H}_{2} \mathrm{~S}$ in triple sugar iron media. Differentiation of $C$. fetus subspecies strains was done by utilizing their tolerance to glycine. Table 1 shows the arrangement of the strains according to their ability to tolerate glycine. Strains which tolerated less than $1 \%$ glycine were referred to as $C$. fetus subsp. venerealis, while strains that tolerated more than $1 \%$ glycine were referred to as $C$. fetus subsp. fetus $(12,23)$. Those strains which tolerated up to $1 \%$ glycine were referred to as $C$. fetus subsp. venerealis biovar "intermedius" $(10,29)$.

Restriction endonuclease analysis of $C$. fetus genome DNA. Genomic DNA of $C$. fetus strains generated six to eight fragments when digested with the restriction endonuclease SmaI (Table 2). Figure 1 shows the PFGE patterns of chromosomal DNA of nine $C$. fetus strains digested with the restriction endonuclease SmaI. Strains UA778 and UA60 ${ }^{\mathrm{T}}$
(Fig. 1, lanes B and C) produced identical patterns. Strains UA809 and UA811 ${ }^{\mathrm{T}}$ (Fig. 1, lanes D and E) also appeared similar. The rest of the $C$. fetus strains produced distinctly different patterns.

The restriction endonuclease $S a l \mathrm{I}$, on the other hand, produced 7 to 10 fragments with genome DNA from the $C$. fetus strains. Genome DNA of $C$. fetus strains, which generated similar patterns when digested with the restriction endonuclease SmaI, appeared to be similar when digested with the restriction endonuclease SalI (Fig. 2).

Determination of genomic sizes of $\boldsymbol{C}$. fetus strains. The size of the genome DNA for each of the strains was calculated from more than six different repetitions of PFGE experiments carried out at different pulse times. The size of each of the DNA fragments was determined by calibration with reference to the $\lambda \Delta 39$ DNA ladder (Fig. 1 and 2). When digested with the restriction endonuclease SmaI, genomic DNA of $C$. fetus strains generated fragments which ranged in size from 50 to $407 \mathrm{~kb}$. The total genome size of the strains was calculated from the sum of the fragment sizes generated by the digested genomic DNA. All C. fetus subsp. fetus strains, a $C$. fetus subsp. venerealis biovar "intermedius" strain (UA790), and two $C$. fetus subsp. venerealis strains (UA810 and UA818) formed a distinct group of genomic sizes which measured $1,134(1,125$ to 1,158$) \mathrm{kb}$, while five $C$. fetus subsp. venerealis strains (UA809, UA811 ${ }^{\mathrm{T}}$, UA816, UA817, and UA820) formed a genomic size group that measured $1,362(1,329$ to 1,394$) \mathrm{kb}$. Four strains of $C$. fetus subsp. venerealis biovar "intermedius" constituted the third group of genomic sizes which measured 1,537 (1,519 to $1,581) \mathrm{kb}$. Similar results were obtained with the restriction endonuclease SalI. 
TABLE 2. Genomic sizes of $C$. fetus

\begin{tabular}{|c|c|c|c|c|}
\hline \multirow{3}{*}{$\begin{array}{l}\text { UA } \\
\text { no. }\end{array}$} & \multicolumn{4}{|c|}{ PFGE pattern with: } \\
\hline & \multicolumn{2}{|c|}{ SmaI } & \multicolumn{2}{|c|}{ SalI } \\
\hline & $\begin{array}{c}\text { No. of } \\
\text { fragments }\end{array}$ & $\begin{array}{c}\text { Genome } \\
\text { size }(\mathrm{kb})^{a}\end{array}$ & $\begin{array}{c}\text { No. of } \\
\text { fragments }\end{array}$ & $\begin{array}{c}\text { Genome } \\
\text { size }(k b)^{a}\end{array}$ \\
\hline 777 & 6 & $1,125 \pm 3$ & 8 & $1,141 \pm 5$ \\
\hline 778 & 6 & $1,125 \pm 3$ & 10 & $1,137 \pm 2$ \\
\hline 779 & 6 & $1,125 \pm 3$ & 8 & $1,125 \pm 5$ \\
\hline 780 & 6 & $1,125 \pm 3$ & 7 & $1,141 \pm 5$ \\
\hline 781 & 8 & $1,158 \pm 2$ & 7 & $1,146 \pm 3$ \\
\hline 782 & 8 & $1,158 \pm 3$ & 8 & $1,139 \pm 5$ \\
\hline 790 & 7 & $1,138 \pm 5$ & 7 & $1,125 \pm 5$ \\
\hline 810 & 7 & $1,152 \pm 5$ & 7 & $1,124 \pm 5$ \\
\hline 818 & 6 & $1,165 \pm 7$ & 9 & $1,139 \pm 2$ \\
\hline $60^{\mathrm{T}}$ & 6 & $1,125 \pm 2$ & 9 & $1,137 \pm 2$ \\
\hline 791 & 8 & $1,529 \pm 4$ & 10 & $1,572 \pm 4$ \\
\hline 813 & 7 & $1,527 \pm 2$ & 10 & $1,579 \pm 2$ \\
\hline 814 & 8 & $1,581 \pm 4$ & 9 & $1,522 \pm 5$ \\
\hline 815 & 8 & $1,519 \pm 3$ & 9 & $1,579 \pm 6$ \\
\hline 809 & 7 & $1,329 \pm 5$ & 7 & $1,329 \pm 5$ \\
\hline $811^{\mathrm{T}}$ & 8 & $1,329 \pm 6$ & 7 & $1,334 \pm 2$ \\
\hline 816 & 8 & $1,394 \pm 2$ & 7 & $1,354 \pm 3$ \\
\hline 817 & 8 & $1,394 \pm 3$ & 7 & $1,362 \pm 3$ \\
\hline 820 & 7 & $1,374 \pm 5$ & 7 & $1,368 \pm 4$ \\
\hline
\end{tabular}

${ }^{a}$ Determined from at least six different gel runs at different pulse times.

DNA-DNA hybridization. Whole chromosomal DNA of $C$. fetus subsp. fetus $\mathrm{UA} 60^{\mathrm{T}}$ was hybridized under high-stringency conditions of hybridization and washing to Southern blots prepared from pulsed-field gels containing DNA of different $C$. fetus subspecies. There appeared to be significant homology between $\mathrm{UA} 60^{\mathrm{T}}$ and the various $C$. fetus

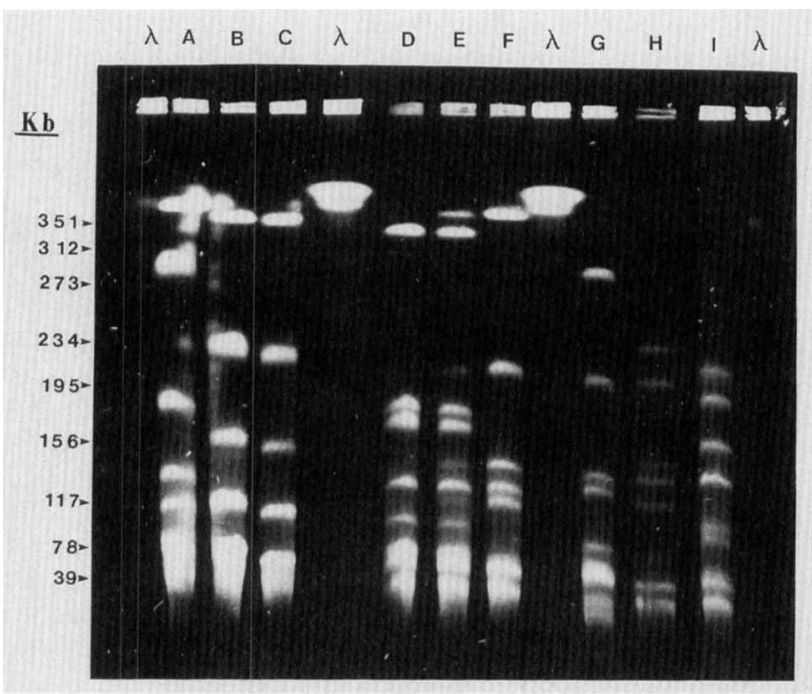

FIG. 1. CHEF gel electrophoresis of $C$. fetus DNA digested with SmaI. DNA was subjected to electrophoresis for $24 \mathrm{~h}$ at $175 \mathrm{~V}$ and $8^{\circ} \mathrm{C}$ with a pulse time of $25 \mathrm{~s}$ in a $1 \%$ agarose gel. Bacteriophage $\lambda \Delta 39$ concatemers were used to determine the fragment sizes. Lanes: A, UA777; B, UA778; C, UA60 ${ }^{\mathrm{T}}$; D, UA809; E, UA811 ${ }^{\mathrm{T}}$; F, UA812; G, UA813; H, UA814; I, UA815. Lanes A to C, C. fetus subsp. fetus; lanes D to F, C. fetus subsp. venerealis; lanes $G$ to I, C. fetus subsp. venerealis biovar "intermedius."

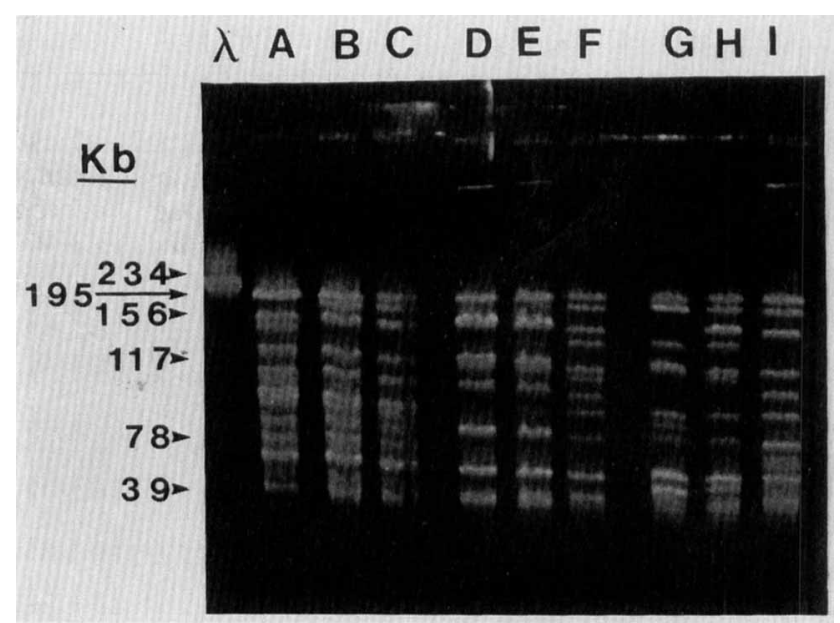

FIG. 2. CHEF gel electrophoresis of $C$. fetus DNA digested with SalI. DNA was subjected to electrophoresis for $24 \mathrm{~h}$ at $175 \mathrm{~V}$ and $8^{\circ} \mathrm{C}$ with a pulse time of 15 to $20 \mathrm{~s}$ in a $1 \%$ agarose gel. Bacteriophage $\lambda \Delta 39$ concatemers were used to determine the fragment sizes. Lanes: A, UA777; B, UA778; C, UA60 ${ }^{\mathrm{T}}$; D, UA809; E, UA811 ${ }^{\mathrm{T}}$; F, UA812; G, UA813; H, UA814; I, UA815. Lanes A to C, C. fetus subsp. fetus; lanes D to F, C. fetus subsp. venerealis; lanes $\mathrm{G}$ to I, C. fetus subsp. venerealis biovar "intermedius."

subspecies. In none of the strains was any major region of nonhomology visible by this technique.

\section{DISCUSSION}

The current classification of the subspecies of $C$. fetus was proposed by Véron and Chatelaine (29) and Smibert (24) and is recognized by the recent editions of Bergey's Manual of Systematic Bacteriology (24) and the Approved Lists of Bacterial Names (22). This classification was based on two main criteria: the ability of these campylobacters to grow on media containing variable concentrations of glycine and the normal habitat of these organisms. Chang and Ogg $(8,9)$ have shown that the glycine characteristic may not be reliable for separating the etiologic agents of vibrionic abortion and bovine vibriosis into the subspecies fetus and venerealis, respectively. These workers have demonstrated that transduction of the glycine tolerance character was accomplished with a bacteriophage from a glycine-resistant donor to a glycine-sensitive recipient strain of $C$. fetus. Moreover, they showed that glycine resistance could occur as a result of spontaneous mutation (9). These facts emphasized the need for a more reliable method for identifying the two subspecies.

PFGE is capable of separating large fragments of chromosomal DNA, which have been digested with restriction endonucleases, to produce a pattern that can help in the differentiation of strains. It was applied successfully to differentiate organisms at the species level (15). Furthermore, this technique is used to differentiate strains within the species and has proved to be useful in epidemiological studies of a variety of microorganisms $(1,2,12,19,28,31$, 32). Moreover, it facilitates the calculation of the DNA genome size (7). As with other campylobacters $(7,31,32)$, we have been able to measure the sizes of genomic DNA from different $C$. fetus strains. The strains clustered in three distinct groups of genomic sizes, i.e., $1.1,1.3$, and $1.5 \mathrm{Mb}$. Genome sizes of strains of $C$. fetus subsp. fetus, including the type strain ATCC 27374 (UA60), measured $1.1 \mathrm{Mb}$; 
however, three more strains (UA790, UA810, and UA818), which showed lower tolerance to glycine (up to $1.0 \%$ ), also belonged to this group. The consistency of the genomic sizes and the findings of Chang and Ogg $(8,9)$ suggest that these strains may actually belong to the $C$. fetus subsp. fetus group. These findings are concordant with those of Chang and Taylor (7), who found that $C$. fetus subsp. fetus UA60 has a smaller genomic size $(1.2 \mathrm{Mb})$ than do the closely related $C$. jejuni $(1.7 \mathrm{Mb})$ and $C$. coli $(1.7 \mathrm{Mb})$. The findings of Chang and Taylor were described as preliminary and were made with one strain (7). During our study, we calculated the genome size of $U A 60^{\mathrm{T}}$ from at least six repeated runs with different pulse times and concluded that 1.12 to $1.14 \mathrm{Mb}$, which is within the range of sizes for the rest of the $C$. fetus subsp. fetus strains (Table 2), represents the actual genomic size of this strain. Strains of $C$. fetus subsp. venerealis, which tolerated $0.6 \%$ glycine in the media, including the type strain ATCC 19438 (UA811), were clustered together by their genomic sizes and measured $1.3 \mathrm{Mb}$. This study confirms the current classification of $C$. fetus $(24,29)$. Moreover, strains of $C$. fetus subsp. venerealis biovar "intermedius" were differentiated from $C$. fetus subsp. venerealis by their genome size (1.5 Mb).

The results of the DNA-DNA hybridization experiments confirm what was previously observed (12), namely, that strains of $C$. fetus are very highly related at the DNA level. However, the degree of DNA-DNA and DNA-rRNA homology and sequence analysis of the $5 S$ and $16 \mathrm{~S}$ rRNAs are still needed to further confirm the classification of these microorganisms (20).

Since the genomic size of a species or a subspecies represents a relatively stable character $(1,2,28,31,32)$, PFGE could provide, especially for the veterinary laboratory, a novel technique that will discriminate between the subspecies of $C$. fetus with more consistency than the phenotypic characterization of these relatively biochemically inert organisms. Furthermore, different strains produce different PFGE patterns, a phenomenon that can be of great value in epidemiological studies of $C$. fetus.

This study also provides genotypic confirmation of a human isolate (UA809) which was identified by its phenotypic characterizations as belonging to the subspecies venerealis. In fact, two more human isolates received recently were also identified as belonging to the subspecies venerealis (data not shown). This is the first report of a human isolate of C. fetus subsp. venerealis.

\section{ACKNOWLEDGMENTS}

We thank all those who supplied strains shown in Table 1 . This work was supported in part by funding from the Canadian Bacterial Diseases Network Research Program to D.E.T., who is a Heritage Medical Scientist.

\section{REFERENCES}

1. Anderson, D. J., J. S. Kuhns, M. L. Vasil, D. N. Gerding, and E. N. Janoff. 1991. DNA fingerprinting by pulsed field gel electrophoresis and ribotyping to distinguish Pseudomonas cepacia isolates from a nosocomial outbreak. J. Clin. Microbiol. 29:648-649.

2. Arbeit, R. D., M. Arthur, R. Dunn, C. Kim, R. K. Selander, and R. Goldstein. 1990. Resolution of recent evolutionary divergence among Escherichia coli from related lineages: the application of pulsed-field electrophoresis to molecular epidemiology. J. Infect. Dis. 161:230-235.

3. Basden, E. H., II, M. E. Tourtellotre, W. N. Plastridge, and J. S. Tucker. 1968. Genetic relationship among bacteria classified as vibrios. J. Bacteriol. 95:439-443.
4. Blaser, M. J. 1986. Extraintestinal Campylobacter infections. West. J. Med. 144:353-354.

5. Blaser, M. J., and E. C. Gotschlich. 1990 . Surface array protein of Campylobacter fetus. J. Biol. Chem. 265:14529-14535.

6. Blaser, M. J., H. L. Hardesty, B. W. Powers, and W.-L. L. Wang. 1980. Survival of Campylobacter fetus subsp. jejuni in biological milieus. J. Clin. Microbiol. 11:309-313.

7. Chang, N., and D. E. Taylor. 1990. Use of pulsed-field gel electrophoresis to size genomes of Campylobacter species and to construct a SalI map of Campylobacter jejuni UA580. J. Bacteriol. 172:5211-5217.

8. Chang, W.-J., and J. E. Ogg. 1970. Transduction in Vibrio fetus. Am. J. Vet. Res. 31:919-924.

9. Chang, W.-J., and J. E. Ogg. 1971. Transduction and mutation to glycine tolerance in Vibrio fetus. Am. J. Vet. Res. 32:649653.

10. Elazhary, M. 1968. An assay of isolation and identification for some animal vibrios and of elucidation of their pathological significance. Meded. Veeartssch. Rijksuniv. Gent 12(2):1-80.

11. Florent, A. 1959. Les deux vibrioses genitales: la vibriose due a $V$. fetus intestinalis Meded. Veeartssch. Rijksuniv. Gent 3(3): $1-60$.

12. Garcia, M. M., M. D. Eaglesome, and C. Rigby. 1983. Campylobacters important in veterinary medicine. Vet. Bull. 53:793-818.

13. Goering, R. V., and T. D. Duensing. 1990. Rapid field inversion gel electrophoresis in combination with an rRNA gene probe in the epidemiological evaluation of staphylococci. J. Clin. Microbiol. 28:426-429.

14. Guerrent, R. L., R. G. Lahita, C. W. Washington, and R. B. Roberts. 1978. Campylobacteriosis in man: pathogenic mechanisms and review of 91 bloodstream infections. Am. J. Med. 65:584-591.

15. Howard, P. J., K. D. Harsono, and J. B. Luchansky. 1992. Differentiation of Listeria monocytogenes, Listeria innocua, Listeria ivanovii, and Listeria seeligeri by pulsed-field gel electrophoresis. Appl. Environ. Microbiol. 58:709-712.

16. Maniatis, T., E. F. Fritsch, and J. Sambrook. 1982. Molecular cloning: a laboratory manual. Cold Spring Harbor Laboratory, Cold Spring Harbor, N.Y.

17. Marsh, H., and B. D. Firehammer. 1953. Serological relationships of twenty-three ovine and three bovine strains of Vibrio fetus. Am. J. Vet. Res. 14:396-398.

18. McCoy, E. C., D. Doyle, K. Burda, L. B. Corbel, and J. Winter. 1975. Superficial antigens of Campylobacter (Vibrio) fetus: characterization of an antiphagocytic component. Infect. Immun. 11:517-525.

19. Murray, B. E., K. V. Singh, S. M. Markowitz, H. A. Lapardo, J. E. Patterson, M. J. Zervos, E. Rubeglio, G. M. Eliopoulos, L. B. Rice, F. W. Goldstein, S. G. Jenkins, G. M. Caputo, R. Masuas, L. S. Moore, E. S. Wang, and G. Weinstock. 1991. Evidence for clonal spread of single strain of $\beta$-lactamase producing Enterococcus (Streptococcus) fecalis to six hospitals in five states. J. Infect. Dis. 163:780-785.

20. Murray, R. G. E., D. J. Brenner, R. R. Colwell, P. De Vos, M. Goodfellow, P. A. D. Grimont, N. Pfenning, E. Stackebrandt, and G. A. Zavarzin. 1990. Report of the Ad Hoc Committee on Approaches to Taxonomy within the Proteobacteria. Int. J. Syst. Bacteriol. 40:213-215.

21. Samuelson, J. D., and J. A. Winter. 1966. Bovine vibriosis: the nature of the carrier state in the bull. J. Infect. Dis. 116:581-592.

22. Skerman, V. B. D., V. McGowan, and P. H. A. Sneath. 1980. Approved lists of bacterial names. Int. J. Syst. Bact. 30:225420.

23. Smibert, R. M. 1981. The genus Campylobacter, p. 609-617. In M. P. Starr, H. Stolp, H. G. Trüper, A. Balows, and H. G. Schlegel (ed.), The prokaryotes. A handbook on habitats, isolation, and identification of bacteria. Springer-Verlag, New York.

24. Smibert, R. M. 1984. Genus Campylobacter Sebald and Véron $1963,907^{\text {AL }}$, p. 111-118. In N. R. Krieg and H. G. Holt (ed.), Bergey's manual of systematic bacteriology, vol. 1. The Williams \& Wilkins Co., Baltimore.

25. Smith, T. 1918. Spirilla associated with disease of the fetal 
membranes in cattle (infectious abortion). J. Exp. Med. 28:701719.

26. Smith, T., and M. S. Taylor. 1919. Some morphological characters of the spirilla (Vibrio fetus, $\mathbf{N}$ sp.) associated with disease of the fetal membranes in cattle. J. Exp. Med. 30:299-311.

27. Southern, E. M. 1975 . Detection of specific sequences among DNA fragments separated by gel electrophoresis. J. Mol. Biol. 98:503-517.

28. Tanskanen, E. I., D. L. Tulloch, A. J. Hillier, and B. E. Davidson. 1990. Pulsed-field gel electrophoresis of SmaI digests of lactococcal genomic DNA, a novel method of strain identification. Appl. Environ. Microbiol. 56:3105-3111.

29. Véron, M., and R. Chatelain. 1973. Taxonomic study of the genus Campylobacter Sabald and Véron and designation of the neotype strain for the type species, Campylobacter fetus (Smith and Taylor) Sabald and Véron. Int. J. Syst. Bacteriol. 23:122134.

30. Winter, A. J., E. C. McCoy, C. S. Burda, and P. J. Bier. 1978. Microcapsule of Campylobacter fetus: chemical and physical characterization. Infect. Immun. 22:963-971.

31. Yan, W., N. Chang, and D. E. Taylor. 1991. Pulsed-field gel electrophoresis of Campylobacter jejuni and Campylobacter coli genomic DNA and its epidemiologic application. J. Infect. Dis. 163:1068-1072.

32. Yan, W., and D. E. Taylor. 1991. Sizing and mapping of the genome of Campylobacter coli strain UA417 using pulsed-field gel electrophoresis. Gene 101:117-120. 